\title{
Agnieszka-Szmelter-Jarosz
}

Department of Logistics, Faculty of Economics, University of Gdańsk, Poland

\section{DEMATEL METHOD IN SUPPLIER EVALUATION AND SELECTION}

\begin{abstract}
The increasing complexity of supply chains creates a number of areas that need to be optimized. Complicated relations between different actors on various markets indicate the need for simplification of the decision-making process and, at the same time, being focused on the organization's goals and needs. The development of multi-criteria methods of supporting decision making applies in particular to the area of logistics support, including supply management. One of the methods widely used in this field is the DEMATEL method, which is a classical approach to evaluate suppliers according to survey or interview results. The article aims to present the application of the supplier evaluation procedure according to the criteria indicated by the decision-makers as significant. The literature review was used for specifying the variables. Then, the evaluation procedure was presented, followed by an empirical example. The paper can be useful for decision-makers both in single organizations and supply chains to improve their evaluation procedures to meet the requirements about which they care the most.
\end{abstract}

Keywords: supplier selection, logistics, procurement, supply management

JEL: C61, D22, L14

\section{Introduction}

Supply chains evolve all the time, trying to respond to dynamic and hard-topredict changes on the global market. The growing complexity of the types of their elements and the number and types of relations between them cause emerging new problems in supply chain management, including the supply area (Nazma Sultana et al., 2016). New logistics strategies should be the answer for new obstacles within the material and non-material flows, with special regard to the growing role 
of information logistics (Weiland, 2018; Wierzbowski, 2018), including the cooperation within information sharing and the Internet of Things (Hsu, Yeh, 2017).

The evolution of those supply chains is the reason why all the functional areas of logistics management need to be continuously improved. One of them is supply management, the procure-to-pay process, as one of the basic logistics processes. A part of the process is supplier selection and evaluation, very much related to the supply strategy. This area will be the main focus of this study.

The aim of the paper is to present the usefulness of the DEMATEL method in supplier selection and evaluation. The study is organized as follows. Firstly, a brief description of the literature review is presented to highlight the main areas of the supplier selection and evaluation process. Additionally, the methods used for calculating the results within those areas are mentioned in this section. The next part presents the variables collected in the review as important for the calculation of the final results, the research procedure and the DEMATEL method itself. In the results section, the implementation of the method is described and the final scores are interpreted. In the last section the paper is concluded, its limitations are indicated, and some possible future research directions are drawn.

\section{Supplier selection and evaluation}

Supply management is one of the main parts of supply chain management. Suppliers are selected according to previously identified and confirmed criteria, important for decision-makers. For many years this problem has been addressed by a huge amount of academic papers, trying to adjust the statistical and mathematical methods to real decision-making problems (Hald, Ellegaard, 2011). Logistics strategies in this area have been also developed. Within this group, the following should be mentioned: built-to-order, build-to-stock, lean management, agile management, vendor managed inventory, single sourcing, double sourcing, multi-sourcing, just-in-time, just-in-sequence and mixed approaches.

Suppliers play a crucial role in shaping the logistics strategies of single companies and whole supply chains (Shaik, Abdul-Kader, 2018). The postponement strategies and implementation of different types of supplier parks have changed the balance of power in supply chains. Mega-suppliers are often treated as integrators of 1st and 2nd tier suppliers (Szmelter-Jarosz, 2018). Supply selection highly impacts the supply chain relationships, and the score of the supply chain itself (in different fields: effectiveness, efficiency, lead-time, etc.) (Chang et al., 2011).

A basic element of the supplier evaluation is the identification of important variables. They are different in the case of small and medium enterprises (Madoranova, Horvath, 2013; Politis et al., 2010), and big corporations, usually using a wide range of criteria and subcriteria. They are different when creating a new product, developing and improving existing products, and in standard procurement procedures within long-term supplier-customer cooperation (Madoranova, Horvath, 2013). A prevalent approach is to define key performance indicators as goals to be achieved by suppliers (Imeri et al., 2014). A popular approach is multi-attribute 
decision making (especially in the area of supplier selection) and using multi-criteria methods (Zhan, 2019).

The set of methods used for measuring industrial performance is very wide and includes both qualitative and quantitative ones (Nazma Sultana et al., 2016). The methods most often used in this group for supplier evaluation are the weighted average method, QFD (Quality Function Deployment), regression analysis (Chang et al., 2011), DEMATEL-ANP-VIKOR (Lee et al., 2013; Nazma Sultana et al., 2016; Shaik, Abdul-Kader, 2018), AHP (Politis et al., 2010), ANOVA, the multi-attribute granulation approach (Zhan, 2019), supported by surveys and interviews.

\section{Methodology}

\subsection{Research procedures and variables}

The first step to achieve the stated goal of the study was to create a research framework and procedure to clarify the process of obtaining final results (see Figure 1). Firstly, the literature study was conducted to identify the variables which should be analyzed in the further collecting of primary data. This set of criteria was presented to three different teams of people working within the supply area of one company to make the assessment process less biased. This feedback from decision-makers, responsible for contacts with suppliers in their everyday work, was supposed to present only initial use of the selected method and will be developed in future research. The mentioned teams had to assess the relations between variables important for supplier selection and evaluation. Then, according to the method, calculations were carried out to evaluate the results and refine the list of the most important variables (criteria) within the mentioned process.

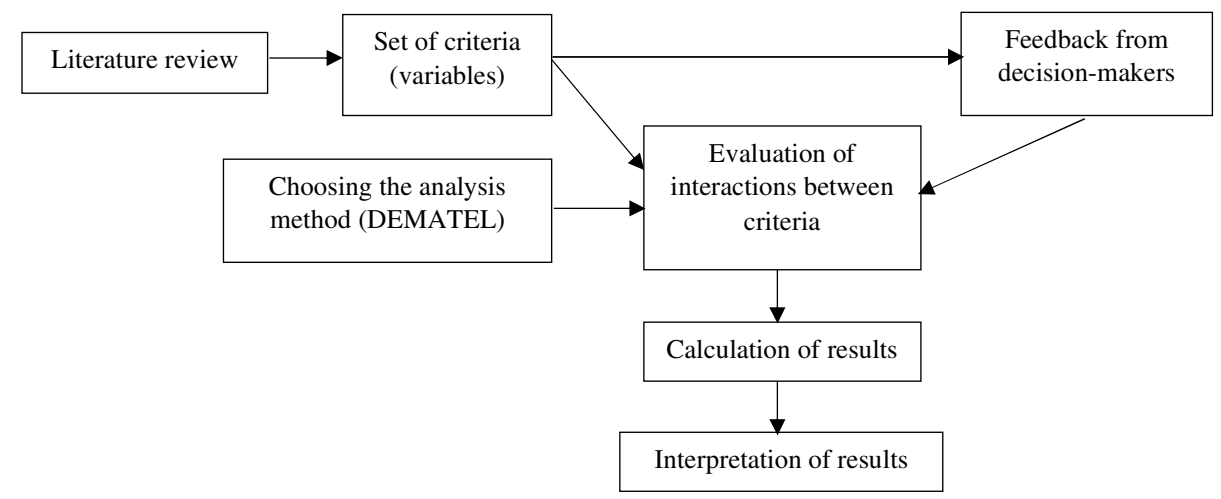

Figure 1. Research framework

Source: (own elaboration)

As mentioned before, the literature review allowed defining a list of important variables which may have an impact on a real assessment of suppliers within supply chain management. Those criteria were described in different literature items, 
although some appeared in every study, like price conditions, on-time delivery and quality of products (see Table 1).

\subsection{DEMATEL method}

Multi-criteria decision-making methods help to manage different types of data (qualitative and quantitative) with a large number of criteria and their possible values, high flexibility to take into consideration the preferences of decision-makers. They have value for decision-makers when they are easy to use and understand (Politis et al., 2010). The classical methods for such analyses are AHP, ANP and DEMATEL (Shaik, Abdul-Kader, 2018). Nowadays, those methods in the modified form (fuzzy DEMATEL, hybrid DEMATEL and AHP) are often used to solve decision-making problems, including but not limited to such as TOPSIS MDCM, PROMETHEE, grey DEMATEL (Chang et al., 2011; Govindan, Chaudhuri, 2016; Nazma Sultana et al., 2016; Shaik, Abdul-Kader, 2018). Both method groups enable including many needs of different stakeholders or decision-makers into the analysis.

The Decision-Making Trial and Evaluation Laboratory (DEMATEL) is a method best suited for analyzing the interrelationship and interdependencies by neglecting the sample size limitation (Govindan, Chaudhuri, 2016). Therefore, it is good for a small number of respondents or, sometimes, groups of respondents (for example project teams). First used for social problems research in 1973 (Gabus, Fontela, 1973), with time, it has become a classical method for multi-criteria analysis in economic science. Its main benefit is the possibility to identify the core driving factors of a specific problem based on interactions and relationships between the criteria specified for the specific problem (Morauszki, Attila, 2015; Torbacki, 2017).

Table 1. List of variables

\begin{tabular}{|c|c|c|c|}
\hline No. & Criteria & Description & Source \\
\hline 1 & Quality & $\begin{array}{l}\text { Measuring the quality, assessing } \\
\text { quality, implementation } \\
\text { of quality standards, continuous } \\
\text { improvement, customer service }\end{array}$ & $\begin{array}{l}\text { (Chang et al., 2011; Govindan et al., } \\
\text { 2016; Govindan, Chaudhuri, 2016; } \\
\text { Kawa, Koczkodaj, 2015; Mirmousa, } \\
\text { Dehnavi, 2016) }\end{array}$ \\
\hline 2 & $\begin{array}{l}\text { Services } \\
\text { and products }\end{array}$ & Portfolio of services and products & $\begin{array}{l}\text { (Chang et al., 2011; Govindan et al., } \\
\text { 2016; Mirmousa, Dehnavi, 2016) }\end{array}$ \\
\hline 3 & Flexibility & $\begin{array}{l}\text { Ability to accommodate a special } \\
\text { or non-routine request, reaction } \\
\text { to demand change }\end{array}$ & $\begin{array}{l}\text { (Chang et al., 2011; Govindan et al., } \\
\text { 2016; Govindan, Chaudhuri, 2016; } \\
\text { Kawa, Koczkodaj, 2015; Mirmousa, } \\
\text { Dehnavi, 2016) }\end{array}$ \\
\hline 4 & Price & $\begin{array}{l}\text { Attractiveness of price lists, cost } \\
\text { reduction programs, programs for } \\
\text { big and loyal customers }\end{array}$ & $\begin{array}{l}\text { (Chang et al., 2011; Govindan et al., } \\
\text { 2016; Govindan, Chaudhuri, 2016; } \\
\text { Kawa, Koczkodaj, 2015; Mirmousa, } \\
\text { Dehnavi, 2016) }\end{array}$ \\
\hline 5 & $\begin{array}{l}\text { Production } \\
\text { capability }\end{array}$ & $\begin{array}{l}\text { Production capacity, production } \\
\text { planning process and scheme, } \\
\text { lead-time }\end{array}$ & $\begin{array}{l}\text { (Chang et al., 2011; Falatoonitoosi } \\
\text { et al., 2014; Govindan et al., 2016; } \\
\text { Kawa, Koczkodaj, 2015) }\end{array}$ \\
\hline
\end{tabular}




\begin{tabular}{|c|c|c|c|}
\hline No. & Criteria & Description & Source \\
\hline 6 & $\begin{array}{l}\text { Technical } \\
\text { capability }\end{array}$ & $\begin{array}{l}\text { Modern technology, research } \\
\text { and development programs, } \\
\text { modern equipment, traceability, } \\
\text { tracking, level of innovations, } \\
\text { research and development }\end{array}$ & $\begin{array}{l}\text { (Chang et al., 2011; Govindan } \\
\text { et al., 2016; Kawa, Koczkodaj, 2015; } \\
\text { Mirmousa, Dehnavi, 2016) }\end{array}$ \\
\hline 7 & $\begin{array}{l}\text { Reliability } \\
\text { of delivery, } \\
\text { security }\end{array}$ & $\begin{array}{l}\text { Timely delivery, safety } \\
\text { of transactions, including transport }\end{array}$ & $\begin{array}{l}\text { (Chang et al., 2011; Kawa, } \\
\text { Koczkodaj, 2015; Mirmousa, } \\
\text { Dehnavi, 2016) }\end{array}$ \\
\hline 8 & Communication & $\begin{array}{l}\text { Information sharing scheme, } \\
\text { openness for cooperation, } \\
\text { IT solutions }\end{array}$ & $\begin{array}{l}\text { (Govindan et al., 2016; Govindan, } \\
\text { Chaudhuri, 2016; Mirmousa, } \\
\text { Dehnavi, 2016) }\end{array}$ \\
\hline 9 & $\begin{array}{l}\text { Financial } \\
\text { stability }\end{array}$ & $\begin{array}{l}\text { Financial performance confirming } \\
\text { continuity of providing products } \\
\text { and services, fixed assets } \\
\text { management }\end{array}$ & $\begin{array}{l}\text { (Govindan et al., 2016; Kawa, } \\
\text { Koczkodaj, 2015; Mirmousa, } \\
\text { Dehnavi, 2016) }\end{array}$ \\
\hline 10 & $\begin{array}{l}\text { Trust } \\
\text { and reputation }\end{array}$ & $\begin{array}{l}\text { Brand awareness, trust to the brand, } \\
\text { opinions of business partners }\end{array}$ & $\begin{array}{l}\text { (Govindan et al., 2016; Mirmousa, } \\
\text { Dehnavi, 2016) }\end{array}$ \\
\hline 11 & $\begin{array}{l}\text { Environmental } \\
\text { management }\end{array}$ & $\begin{array}{l}\text { Green design, ISO 14000, pollution } \\
\text { control, eco-labelling, life cycle } \\
\text { management, greenness }\end{array}$ & $\begin{array}{l}\text { (Falatoonitoosi et al., 2014; } \\
\text { Mirmousa, Dehnavi, 2016) }\end{array}$ \\
\hline 12 & Experience & $\begin{array}{l}\text { History of operating on the market, } \\
\text { history of company development }\end{array}$ & $\begin{array}{l}\text { (Govindan et al., 2016; Kawa, } \\
\text { Koczkodaj, 2015; Mirmousa, } \\
\text { Dehnavi, 2016) }\end{array}$ \\
\hline 13 & Location & $\begin{array}{l}\text { Location and geographical scope } \\
\text { of deliveries }\end{array}$ & (Govindan et al., 2016) \\
\hline 14 & $\begin{array}{l}\text { Human } \\
\text { resources } \\
\text { management }\end{array}$ & $\begin{array}{l}\text { Talent management, employee skills } \\
\text { improvement programs }\end{array}$ & (Govindan et al., 2016) \\
\hline
\end{tabular}

Source: (own elaboration)

The DEMATEL method allows separating a factor into cause and effect groups (Chang et al., 2011) and identifying the most important criteria from the group of all criteria indicated as crucial in the decision-making process according to stakeholder needs. The main result of the analysis is an impact digraph map. The key factor criteria in the field of supplier evaluation show supplier performance and provide valuable data on supplier selection in the case of pre-purchase activities.

DEMATEL was used to solve multiple logistics problems, like the performance of reverse logistics enterprises (Shaik, Abdul-Kader, 2018), risk management of third party logistics service providers (Govindan et al., 2016; Govindan, Chaudhuri, 2016), supply chain risk management (Govindan, Chaudhuri, 2016), remanufacturing barriers, supply chain performance, city logistics, green supply chains (Govindan, Chaudhuri, 2016), the Internet of Things (Hsu, Yeh, 2017), 3PL selection (Govindan et al., 2016), using ERP systems (Torbacki, 2017). It was used for transport and logistics (Duchaczek, 2015; Torbacki, 2017), also the problem of supplier selection (Chang et al., 2011; Falatoonitoosi et al., 2014; Govindan, Chaudhuri, 2016; Lee et al., 2013; Mirmousa, Dehnavi, 2016; Shaik, Abdul-Kader, 2018).

The DEMATEL method contains several steps to reach the final value. Those are described below. 
Step 1. Calculating direct relation matrix A

After collecting assessments from decision-makers concerning their opinion about relations between variables (see Table 2), the direct relation matrix should be calculated (see Equation 1). Usually, the results in the matrix are average values from all the results obtained from the surveyed persons or groups.

Table 2. DEMATEL scale

\begin{tabular}{|l|c|}
\hline \multicolumn{1}{|c|}{ Type of relations between variables } & Influence score \\
\hline No influence & 0 \\
\hline Very low influence & 1 \\
\hline Low influence & 2 \\
\hline High influence & 3 \\
\hline Very high influence & 4 \\
\hline
\end{tabular}

Source: (own elaboration based on: Chang et al., 2011)

Equation 1. Matrix A

$$
\mathrm{A} \square=\left[\begin{array}{ccccc}
0 & a_{12} & a_{13} & \ldots & a_{1 n} \\
a_{21} & 0 & a_{23} & \ldots & a_{2 n} \\
\ldots & \ldots & \ldots & \ldots & \ldots \\
\ldots & \ldots & \ldots & \ldots & \ldots \\
a_{n 1} & a_{n 2} & a_{n 3} & \ldots & 0
\end{array}\right]
$$

Step 2. Normalization of matrix A to matrix $\mathrm{S}$

Normalization of the primary matrix is made with the use of equations allowing placing all the elements between 0 and 1 (see Equation 2 and Equation 3).

Equation 2. Matrix S

$$
S=s \times A
$$

Equation 3. Indicator s

$$
S=\min \left[\frac{1}{\max _{i} \sum_{j=1}^{n}\left|a_{i j}\right|} \mid \frac{1}{\max _{j} \sum_{i=1}^{n}\left|a_{i j}\right|}\right]
$$

Step 3. Calculation of total relation matrix $\mathrm{M}$

Matrix $\mathrm{S}$ is used to calculate the total relation matrix (see Equation 4).

Equation 4. Matrix M

$$
M=S(I-S)^{-1}
$$

Step 4. Summing up the rows and columns

In this step, the equation for the sum of rows and columns is solved (see Equation 5 and Equation 6).

Equation 5. Result $r_{i}$

$$
r_{i}=\left[\sum_{j=1}^{n} m_{i j}\right]_{n \times 1}
$$


Equation 6. Result $s_{i}$

$$
s_{i}=\left[\sum_{i=1}^{n} m_{i j}\right] 1 \times n
$$

Step 5. Presenting $r_{i}-s_{i}$ and $r_{i}+s_{i}$ values and causal-effect graph

In the final step, the graph is constructed using $\left(r_{i}+s_{i}\right)$ as the horizontal axis and $\left(r_{i}-s_{i}\right)$ as the vertical axis. The graph allows defining the relationships between the factors and identification of those most important and influential (see Figure 2).

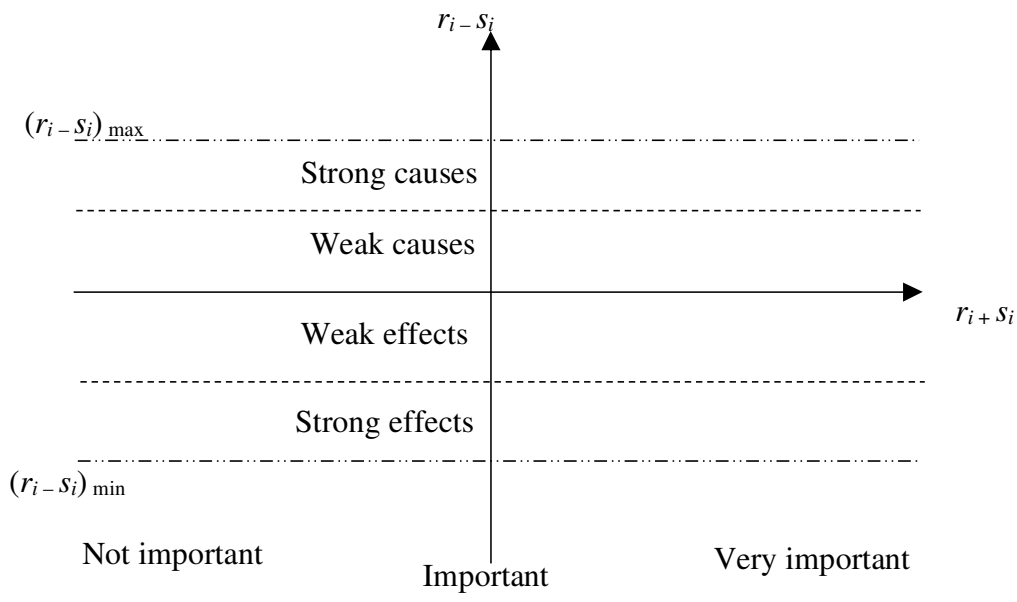

Figure 2. Cause-effect diagram in DEMATEL method

Source: (own elaboration based on: Dytczak et al., 2014)

The higher the value of $r_{i}+s_{i}$, the higher the degree of importance of a given factor in the decision-making process. On the other hand, the $r_{i}-s_{i}$ value defines the general nature of the variable (Dytczak et al., 2014). If this value is greater than 0 , it dominates over other values, if it is negative, it is dominated by other variables. In addition, the location of the result on the scatterplot in the causal-effect plot can be used to determine whether a given variable is a cause or an effect (Sohrabinejad, Rahimi, 2015).

\section{Results and discussion}

According to the previously described research procedure (see Figure 1), the determined variables were presented to three teams of people associated with the procurement process, more precisely - relations with suppliers. The purpose of their evaluation was to describe, using the influence table (Table 1), how strong the relationships between the variables were. The results of this assessment are presented in Table 3 . The values in the table are the arithmetic means of valuations made by the three groups. It was assumed that the decision on the allocation of influence belonged to the assessment teams, so there were no restrictions on the impact 
of individual variables on each other. In some cases, such a restriction is applied, but in this study it has not been implemented, leaving the choice to individual working teams to assign the existence of a relationship between variables or the lack of such.

Table 3. Matrix A - relations between variables (mean values)

\begin{tabular}{|c|c|c|c|c|c|c|c|c|c|c|c|c|c|c|c|}
\hline Criterion & 1 & 2 & 3 & 4 & 5 & 6 & 7 & 8 & 9 & 10 & 11 & 12 & 13 & 14 & Sum \\
\hline 1 & 0.00 & 3.67 & 2.67 & 3.67 & 2.00 & 2.33 & 3.67 & 1.33 & 0.67 & 1.67 & 2.33 & 2.67 & 0.67 & 1.67 & 29.02 \\
\hline 2 & 2.33 & 0.00 & 3.33 & 3.67 & 4.00 & 3.33 & 1.67 & 1.33 & 2.33 & 2.67 & 1.00 & 1.67 & 2.67 & 1.67 & 31.67 \\
\hline 3 & 2.00 & 3.33 & 0.00 & 3.67 & 4.00 & 3.33 & 1.67 & 2.33 & 1.00 & 2.67 & 0.67 & 1.00 & 2.67 & 1.33 & 29.67 \\
\hline 4 & 4.00 & 3.33 & 3.67 & 0.00 & 3.67 & 2.67 & 3.67 & 2.33 & 3.33 & 2.33 & 1.67 & 2.33 & 2.67 & 0.67 & 36.34 \\
\hline 5 & 1.33 & 3.67 & 4.00 & 3.33 & 0.00 & 4.00 & 3.00 & 0.67 & 1.67 & 2.33 & 1.33 & 0.67 & 1.33 & 0.33 & 27.66 \\
\hline 6 & 2.67 & 3.00 & 3.00 & 3.67 & 4.00 & 0.00 & 3.33 & 3.33 & 1.00 & 2.33 & 3.00 & 1.67 & 1.33 & 0.67 & 33.00 \\
\hline 7 & 1.33 & 1.00 & 3.00 & 1.33 & 2.33 & 2.67 & 0.00 & 1.67 & 3.33 & 4.00 & 0.33 & 0.67 & 1.67 & 1.67 & 25.00 \\
\hline 8 & 0.67 & 0.33 & 3.33 & 1.67 & 1.00 & 1.67 & 2.67 & 0.00 & 1.67 & 3.67 & 0.67 & 1.33 & 2.33 & 2.33 & 23.34 \\
\hline 9 & 2.33 & 2.00 & 1.67 & 2.00 & 3.33 & 3.00 & 3.33 & 2.33 & 0.00 & 3.33 & 3.67 & 2.00 & 3.00 & 3.33 & 35.32 \\
\hline 10 & 3.33 & 0.67 & 1.00 & 3.33 & 0.67 & 1.33 & 1.00 & 1.33 & 3.33 & 0.00 & 1.67 & 0.67 & 1.00 & 1.67 & 21.00 \\
\hline 11 & 2.67 & 3.33 & 2.33 & 3.33 & 2.00 & 3.67 & 1.33 & 2.00 & 1.33 & 3.67 & 0.00 & 1.67 & 1.00 & 1.00 & 29.33 \\
\hline 12 & 3.33 & 3.67 & 2.67 & 3.33 & 1.67 & 3.33 & 2.67 & 3.67 & 2.33 & 4.00 & 2.00 & 0.00 & 1.67 & 2.00 & 36.34 \\
\hline 13 & 2.67 & 3.33 & 2.00 & 4.00 & 3.67 & 4.00 & 2.33 & 2.67 & 2.00 & 3.00 & 3.67 & 1.33 & 0.00 & 3.33 & 38.00 \\
\hline 14 & 3.67 & 1.67 & 1.33 & 1.67 & 3.33 & 4.00 & 2.33 & 4.00 & 2.33 & 3.67 & 1.67 & 1.33 & 2.33 & 0.00 & 33.33 \\
\hline Sum & 32.33 & 33.00 & 34.00 & 38.67 & 35.67 & 39.33 & 32.67 & 28.99 & 26.32 & 39.34 & 23.68 & 19.01 & 24.34 & 21.67 & - \\
\hline
\end{tabular}

Source: (own elaboration)

Then, according to the established $s$ (see Equation 7), a normalized matrix $S$ was calculated (see Table 4), which was converted according to Equation 4 into matrix $\mathrm{M}$ (see Table 5). Using Equation 5 and Equation 6, a final matrix was calculated with the data necessary to evaluate the effect of each variable on the supplier's score (see Table 6). The next step was to present the final results using the cause-effect diagram (see Figure 3) and, based on it, prepare an interpretation of the results of the study according to the previously mentioned pattern (see Figure 2).

Equation 7. Empirical s

$$
s=\min \left(\frac{1}{39.34} ; \frac{1}{38}\right)=0.02542
$$

According to the final matrix and cause-effect diagram, the results are related to assigning the variables to the group of causes and effects. In this step, also the strength of being the cause or the effect can be implied. Another dimension is to assess the level of influence on the final grade as weak or strong (important or unimportant variable). 
Table 4. Matrix S

\begin{tabular}{|c|c|c|c|c|c|c|c|c|c|c|c|c|c|c|}
\hline $\mathrm{S}$ & 1 & 2 & 3 & 4 & 5 & 6 & 7 & 8 & 9 & 10 & 11 & 12 & 13 & 14 \\
\hline 1 & 0.00 & 0.09 & 0.07 & 0.09 & 0.05 & 0.06 & 0.09 & 0.03 & 0.02 & 0.04 & 0.06 & 0.07 & 0.02 & 0.04 \\
\hline 2 & 0.06 & 0.00 & 0.08 & 0.09 & 0.10 & 0.08 & 0.04 & 0.03 & 0.06 & 0.07 & 0.03 & 0.04 & 0.07 & 0.04 \\
\hline 3 & 0.05 & 0.08 & 0.00 & 0.09 & 0.10 & 0.08 & 0.04 & 0.06 & 0.03 & 0.07 & 0.02 & 0.03 & 0.07 & 0.03 \\
\hline 4 & 0.10 & 0.08 & 0.09 & 0.00 & 0.09 & 0.07 & 0.09 & 0.06 & 0.08 & 0.06 & 0.04 & 0.06 & 0.07 & 0.02 \\
\hline 5 & 0.03 & 0.09 & 0.10 & 0.08 & 0.00 & 0.10 & 0.08 & 0.02 & 0.04 & 0.06 & 0.03 & 0.02 & 0.03 & 0.01 \\
\hline 6 & 0.07 & 0.08 & 0.08 & 0.09 & 0.10 & 0.00 & 0.08 & 0.08 & 0.03 & 0.06 & 0.08 & 0.04 & 0.03 & 0.02 \\
\hline 7 & 0.03 & 0.03 & 0.08 & 0.03 & 0.06 & 0.07 & 0.00 & 0.04 & 0.08 & 0.10 & 0.01 & 0.02 & 0.04 & 0.04 \\
\hline 8 & 0.02 & 0.01 & 0.08 & 0.04 & 0.03 & 0.04 & 0.07 & 0.00 & 0.04 & 0.09 & 0.02 & 0.03 & 0.06 & 0.06 \\
\hline 9 & 0.06 & 0.05 & 0.04 & 0.05 & 0.08 & 0.08 & 0.08 & 0.06 & 0.00 & 0.08 & 0.09 & 0.05 & 0.08 & 0.08 \\
\hline 10 & 0.08 & 0.02 & 0.03 & 0.08 & 0.02 & 0.03 & 0.03 & 0.03 & 0.08 & 0.00 & 0.04 & 0.02 & 0.03 & 0.04 \\
\hline 11 & 0.07 & 0.08 & 0.06 & 0.08 & 0.05 & 0.09 & 0.03 & 0.05 & 0.03 & 0.09 & 0.00 & 0.04 & 0.03 & 0.03 \\
\hline 12 & 0.08 & 0.09 & 0.07 & 0.08 & 0.04 & 0.08 & 0.07 & 0.09 & 0.06 & 0.10 & 0.05 & 0.00 & 0.04 & 0.05 \\
\hline 13 & 0.07 & 0.08 & 0.05 & 0.10 & 0.09 & 0.10 & 0.06 & 0.07 & 0.05 & 0.08 & 0.09 & 0.03 & 0.00 & 0.08 \\
\hline 14 & 0.09 & 0.04 & 0.03 & 0.04 & 0.08 & 0.10 & 0.06 & 0.10 & 0.06 & 0.09 & 0.04 & 0.03 & 0.06 & 0.00 \\
\hline
\end{tabular}

Source: (own elaboration)

Table 5. Matrix M

\begin{tabular}{|c|c|c|c|c|c|c|c|c|c|c|c|c|c|c|c|}
\hline $\mathrm{M}$ & 1 & 2 & 3 & 4 & 5 & 6 & 7 & 8 & 9 & 10 & 11 & 12 & 13 & 14 & Sum \\
\hline 1 & 0.191 & 0.283 & 0.272 & 0.316 & 0.263 & 0.282 & 0.281 & 0.199 & 0.179 & 0.265 & 0.191 & 0.179 & 0.164 & 0.162 & 3.227 \\
\hline 2 & 0.266 & 0.218 & 0.306 & 0.341 & 0.331 & 0.328 & 0.257 & 0.215 & 0.230 & 0.307 & 0.180 & 0.167 & 0.224 & 0.176 & 3.545 \\
\hline 3 & 0.242 & 0.280 & 0.214 & 0.323 & 0.314 & 0.309 & 0.242 & 0.223 & 0.188 & 0.289 & 0.160 & 0.142 & 0.213 & 0.158 & 3.297 \\
\hline 4 & 0.326 & 0.321 & 0.342 & 0.285 & 0.350 & 0.342 & 0.328 & 0.258 & 0.274 & 0.331 & 0.213 & 0.198 & 0.244 & 0.172 & 3.984 \\
\hline 5 & 0.215 & 0.275 & 0.293 & 0.301 & 0.209 & 0.309 & 0.258 & 0.175 & 0.193 & 0.268 & 0.164 & 0.127 & 0.174 & 0.126 & 3.087 \\
\hline 6 & 0.271 & 0.288 & 0.303 & 0.341 & 0.328 & 0.249 & 0.295 & 0.259 & 0.202 & 0.303 & 0.221 & 0.167 & 0.194 & 0.152 & 3.573 \\
\hline 7 & 0.195 & 0.188 & 0.243 & 0.228 & 0.237 & 0.254 & 0.166 & 0.182 & 0.215 & 0.284 & 0.130 & 0.114 & 0.166 & 0.148 & 2.751 \\
\hline 8 & 0.171 & 0.162 & 0.239 & 0.223 & 0.195 & 0.220 & 0.218 & 0.135 & 0.170 & 0.267 & 0.129 & 0.122 & 0.173 & 0.158 & 2.580 \\
\hline 9 & 0.284 & 0.280 & 0.285 & 0.322 & 0.331 & 0.342 & 0.311 & 0.255 & 0.191 & 0.348 & 0.254 & 0.185 & 0.244 & 0.228 & 3.860 \\
\hline 10 & 0.223 & 0.164 & 0.177 & 0.249 & 0.177 & 0.200 & 0.174 & 0.157 & 0.198 & 0.166 & 0.148 & 0.106 & 0.134 & 0.135 & 2.409 \\
\hline 11 & 0.256 & 0.275 & 0.263 & 0.311 & 0.262 & 0.310 & 0.228 & 0.213 & 0.192 & 0.308 & 0.139 & 0.157 & 0.170 & 0.147 & 3.232 \\
\hline 12 & 0.312 & 0.322 & 0.315 & 0.359 & 0.300 & 0.351 & 0.302 & 0.289 & 0.251 & 0.367 & 0.218 & 0.141 & 0.219 & 0.201 & 3.947 \\
\hline 13 & 0.311 & 0.331 & 0.315 & 0.390 & 0.362 & 0.386 & 0.308 & 0.278 & 0.254 & 0.359 & 0.267 & 0.182 & 0.187 & 0.237 & 4.167 \\
\hline 14 & 0.297 & 0.255 & 0.262 & 0.296 & 0.312 & 0.343 & 0.275 & 0.278 & 0.232 & 0.335 & 0.197 & 0.161 & 0.216 & 0.139 & 3.600 \\
\hline Sum & 3.558 & 3.643 & 3.832 & 4.283 & 3.971 & 4.226 & 3.643 & 3.115 & 2.970 & 4.198 & 2.610 & 2.149 & 2.723 & 2.339 & 47.259 \\
\hline
\end{tabular}

Source: (own elaboration) 
The higher the value of $r_{i}+s_{i}$, the higher the degree of importance of a given variable in the decision-making process, which is the supplier selection or evaluation process. Therefore, looking at the results of calculations, the five most important ones are services and products (portfolio), flexibility, price (the highest score in the results), production and technical capability. What is surprising, the quality, described always as a very important variable, had a lower score than expected.

Table 6. Final matrix

\begin{tabular}{|c|c|c|c|c|}
\hline Criterion & $\mathrm{r}_{\mathrm{i}}$ & $\mathrm{s}_{\mathrm{i}}$ & $\mathrm{r}_{\mathrm{i}}+\mathrm{s}_{\mathrm{i}}$ & $\mathrm{r}_{\mathrm{i}}-\mathrm{s}_{\mathrm{i}}$ \\
\hline 1 & 3.227 & 3.558 & 6.786 & -0.331 \\
\hline 2 & 3.545 & 3.643 & 7.188 & -0.098 \\
\hline 3 & 3.297 & 3.832 & 7.129 & -0.534 \\
\hline 4 & 3.984 & 4.283 & 8.267 & -0.299 \\
\hline 5 & 3.087 & 3.971 & 7.057 & -0.884 \\
\hline 6 & 3.573 & 4.226 & 7.799 & -0.652 \\
\hline 7 & 2.751 & 3.643 & 6.395 & -0.892 \\
\hline 8 & 2.580 & 3.115 & 5.695 & -0.534 \\
\hline 9 & 3.860 & 2.970 & 6.829 & 0.890 \\
\hline 10 & 2.409 & 4.198 & 6.607 & -1.789 \\
\hline 11 & 3.232 & 2.610 & 5.842 & 0.622 \\
\hline 12 & 3.947 & 2.149 & 6.097 & 1.798 \\
\hline 13 & 4.167 & 2.723 & 6.890 & 1.444 \\
\hline 14 & 3.600 & 2.339 & 5.939 & 1.261 \\
\hline
\end{tabular}

Source: (own elaboration)

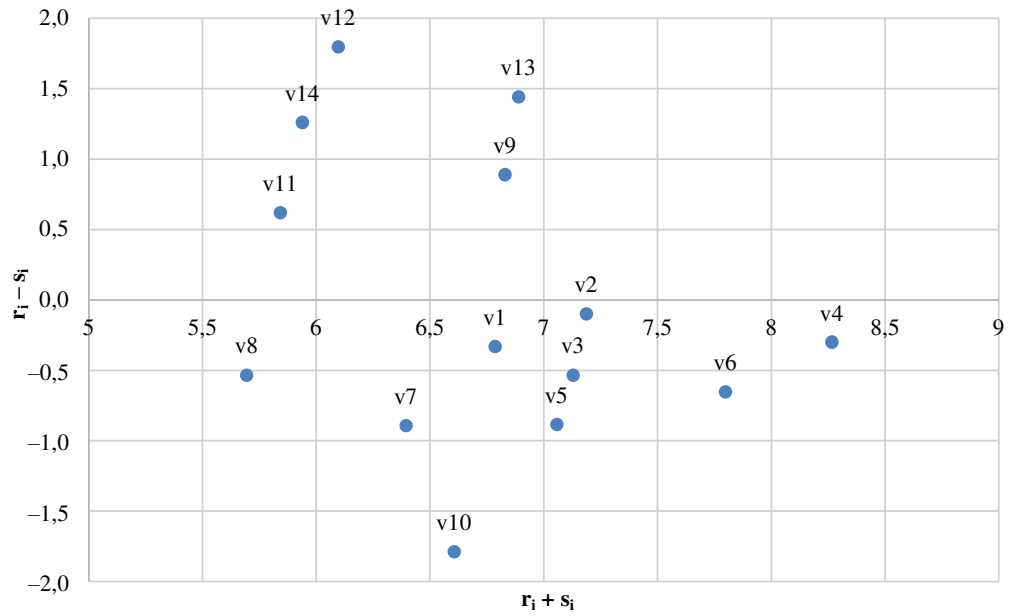

Figure 3. Cause-effect graph

Source: (own elaboration) 
The decision-makers were focused mostly on prices, including special offers for loyal and biggest customers. This is an obvious result. The second score belongs to the technical capability, assumed with many types of innovations, determining also - to some extent - production capability. Research and development may have an impact on the communication, quality, the portfolio of products and services, including tracking of goods and traceability as a whole set of tools aimed at identifying goods within the supply chains. The production capability itself is an important variable. Especially pre-production activities, like production planning and scheduling, are very much correlated with the supplier's flexibility. Also, the comprehensive offer is an attractor, which is highly recommended by assessment teams. If the supplier is reliable, decision-makers may be more willing to order more goods or services from him rather than seeking for another supplier. This confirms the trend in supply chains to closer cooperation with suppliers, the emergence of mega-suppliers or suppliers integrators and shifting from multi-sourcing into single-sourcing, resulting in a long-term cooperation. Taking into account today's complexity of supply chains, rapid changes on the global market and fluctuations of demand, flexibility can be the response to the uncertainty. This variable was also highly rated. Supplier reaction for non-routine requests can be a valuable attitude toward spreading cooperation with subsequent customers.

Looking at the $r_{i}-s_{i}$ values, the general nature of the variable can be determined. The dominating variables in the analysis are financial stability, environmental management, experience, location and human resources management. They influence other factors, thus being the determinants of creating the other variables. The strongest cause in this group is experience, therefore, it has the strongest impact on the other variables. The second score is calculated for location, and the third - for human resources management. They also affect the shaping of variables defined as dependent.

The variables dominated by others are quality, services and products, flexibility, price, production and technical capability, delivery reliability, communication and trust. It is worth noting that trust is the most dependent variable, so its value depends on many other variables.

Those results are similar to those presented in the literature (Chang et al., 2011; Govindan et al., 2016; Mirmousa, Dehnavi, 2016). Although, Morauszki and Attila (2015) reported changes in the importance of criteria over time. Those results of the literature study are totally opposite, with some exceptions, to those presented in this study. In the mentioned literature source, in the 1960s the most important criteria were quality, delivery reliability, performance and warranties. Then, it changed, and 30 years later, the highest ranks were assigned to prices, supplier profitability and financial disclosure records. In 2003, the most important variables in the supplier selection and evaluation were the ability to meet the deadline, quality, technical capability and prices. Those last mentioned are quite compatible with the results presented here. It can be assumed that this set of variables will change over time as it has happened before. 


\section{Conclusions}

The results of this study can hopefully help organizations, especially companies, assess suppliers by focusing on the most crucial factors. The results are ready-touse for the SCM decision-making process, hence, the practical implications can be described as important. The set of variables included in the analysis is based on different results, from literature review studies, thus, they can be described as objective and well-thought-out, and build a full set of criteria important for decision-makers.

The study finds that the most important criterion is the price, the supplier's experience is a dominating issue, and the most relative criterion is trust, being the result of many variables. Usually, in their assessments companies focus on the price, quality and delivery performance only (Chang et al., 2011). However, as this study shows, other factors are also important and should be taken into consideration. The knowledge about the interdependencies between variables and their importance for the final score can serve as a basis for defining the set of criteria for supplier selection and evaluation. In fact, the analysis presented in this study could objectify the process of defining such criteria, often created, as a whole assessment procedure, according to the subjective opinions of one decision-maker.

However, this study has several limitations. Undoubtedly, the literature review is not full and probably, a systematic review could provide additional variables or a possibility of breaking down cumulative variables into detailed ones. Secondly, this study was only an example of using the DEMATEL method on a small group of observations. Presumably, a larger number of assessments would allow objectifying the results to a greater extent. Thirdly, the DEMATEL method is now often modified by researchers to find new ways of calculating the results for complex decision-making processes in the field of logistics, which undoubtedly is the supplier selection and evaluation process. In addressing future work, the framework presented here should be expanded to include more sophisticated mathematical methods, as has been done in many research papers. Exploratory studies will be developed in future research, maybe some more variables will be found as important for the discussed process in terms of logistics management and supply chain management.

Future studies should be focused on customizing the classical multi-criteria decision-making methods to adjust them to the real needs of decision-makers in companies and the goals of organizations and supply chains (Adamus, Gręda, 2005; Lin et al., 2009; Seker, Zavadskas, 2017; Sohrabinejad, Rahimi, 2015). What is worth noting, the direction of SCM towards sustainable green supply chains will affect the future set of important variables, and thus, the calculation of their relations (Falatoonitoosi et al., 2014; Kara, Firat, 2016). If the current trends are still developed at the current pace, also the role of suppliers will change in the forthcoming years. Therefore, supplier evaluation studies will evolve and continue to be one of the most important research areas within the field of logistics. 


\section{References}

Adamus, W., Gręda, A. (2005), Wspomaganie decyzji wielokryterialnych w rozwiązywaniu wybranych problemów organizacyjnych i menedżerskich. Badania Operacyjne i Decyzje, 2(2), pp. 5-36.

Chang, B., Chang, C. W., Wu, C. H. (2011), Fuzzy DEMATEL Method for Developing Supplier Selection Criteria. Expert Systems with Applications, 8(3), pp. 1850-1858, https://doi. org/10.1016/j.eswa.2010.07.114.

Duchaczek, A. (2015), Ocena preferencji decydenta przy wyborze środków transportowych. Budownictwo i Architektura, 14(1), pp. 25-31, https://doi.org/0.1155/2014/396923.

Dytczak, M., Ginda, G., Jastrząbek, B. (2014), Zastosowania metody DEMATEL w transporcie. Czasopismo Logistyka, 6, pp. 3415-3422.

Falatoonitoosi, E., Ahmed, S., Sorooshian, S. (2014), A Multicriteria Framework to Evaluate Supplier's Greenness. Abstract and Applied Analysis, 2014, pp. 1-12.

Gabus, A., Fontela, E. (1973), Perceptions of the World Problematique: Communication Procedure, Communicating with Those Bearing Collective Responsibility. DEMATEL Report No. 1, Battle Geneva Research Centre, Geneva.

Govindan, K., Chaudhuri, A. (2016), Interrelationships of Risks Faced by Third Party Logistics Service Providers: A DEMATEL Based Approach. Transportation Research Part E: Logistics and Transportation Review, 90, pp. 177-195, https://doi.org/10.1016/j.tre.2015.11.010.

Govindan, K., Khodaverdi, R., Vafadarnikjoo, A. (2016), A Grey DEMATEL Approach to Develop Third-Party Logistics Provider Selection Criteria. Industrial Management and Data Systems, 116(4), pp. 690-722, https://doi.org/10.1108/IMDS-05-2015-0180.

Hald, K. S., Ellegaard, C. (2011), Supplier Evaluation Processes: The Shaping and Reshaping of Supplier Performance. International Journal of Operations and Production Management, 31(8).

Hsu, C. W., Yeh, C. C. (2017), Understanding the Factors Affecting the Adoption of the Internet of Things. Technology Analysis and Strategic Management, 29(9), pp. 1089-1102, https://doi. org/10.1080/09537325.2016.1269160.

Imeri, S., Shahzad, K., Takala, J., Liu, Y., Ali, T. (2014), Suppliers' Evaluation: An Empirical Study, pp. 1-10, https://www.researchgate.net/publication/273573968_Suppliers\%27_Evaluation_An_Empirical_Study [Accessed 1 June 2019].

Kara, M. E., Firat, S. U. (2016), Sustainable Supplier Evaluation and Selection Criteria. In: Erdogdu, M., Mermod, A. Y., Yildirim, O. B. A. (Eds.), Social and Economic Perspectives on Sustainability, IJOPEC Publication, London-Istanbul, pp. 159-168.

Kawa, A., Koczkodaj, W. W. (2015), Supplier Evaluation Process by Pairwise Comparisons. Mathematical Problems in Engineering, 2015, pp. 1-9.

Lee, H. S., Tzeng, G. H., Yeih, W., Wang, Y. J., Yang, S. C. (2013), Revised DEMATEL: Resolving the Infeasibility of DEMATEL. Applied Mathematical Modelling, Elsevier Inc., 37(10-11), pp. 6746-6757, https://doi.org/10.1016/j.apm.2013.01.016.

Lin, Z. -P., Wang, R., Tseng, M. -L. (2009), Determination of a Cause and Effect Decision Making Model for Leisure Farm's Service Quality in Taiwan. WSEAS Transactions in Business and Economics, 6(2), pp. 73-86.

Madoranova, M., Horvath, M. (2013), Multi-Criteria Decision Matrix Approach for Supplier Evaluation in Micro and Small Organisations. Quality Innovation Prosperity, 17(1), pp. 120-127, https://doi.org/10.12776/QIP.V17I1.185.

Mirmousa, S., Dehnavi, H. D. (2016), Development of Criteria of Selecting the Supplier by Using the Fuzzy DEMATEL Method. Procedia - Social and Behavioral Sciences, 230(May), pp. 281-289, https://doi.org/10.1016/j.sbspro.2016.09.036. 
Morauszki, K., Attila, L. (2015), Changes in the Ranking of Supplier Evaluation Criteria, $7^{\text {th }}$ International Conference for Young Researchers, Szent István Egyetemi Kiadó, 12-14 November 2012, Gödöll, Hungary, pp. 186-192.

Nazma Sultana, M., Habibur Rahman, M., Al Mamun, A. (2016), Multi Criteria Decision Making Tools for Supplier Evaluation and Selection: A Review. European Journal of Advances in Engineering and Technology, 3(5), pp. 56-65.

Politis, S., Klumpp, M., Celebi, D. (2010), Analytical Hierarchy Process in Supplier Evaluation. $16^{\text {th }}$ International Working Seminar on Production Economics, Conference Proceedings, 3(January), pp. 411-424.

Seker, S., Zavadskas, E. K. (2017), Application of Fuzzy DEMATEL Method for Analyzing Occupational Risks on Construction Sites. Sustainability (Switzerland), 9(11), pp. 1-19, https://doi.org/10.3390/su9112083.

Shaik, M. N., Abdul-Kader, W. (2018), A Hybrid Multiple Criteria Decision Making Approach for Measuring Comprehensive Performance of Reverse Logistics Enterprises. Computers and Industrial Engineering, 123(March), pp. 9-25, https://doi.org/10.1016/j.cie.2018.06.007.

Sohrabinejad, A., Rahimi, M. (2015), Risk Determination, Prioritization, and Classifying in Construction Project Case Study: Gharb Tehran Commercial-Administrative Complex. Journal of Construction Engineering, 2015(January 2016), pp. 1-10, https://doi.org/10.1155/ 2015/203468.

Szmelter-Jarosz, A. (2018), Supplier Parks and Agent-based Technologies as Efficient Solutions for Complexity Management in Automotive Industry. Research Journal of University of Gdańsk. Transport Economics and Logistics, 78, pp. 113-132, http://dx.doi.org/10.26881/ etil.2018.78.10.

Torbacki, W. (2017), Dematel Method in ERP Systems for TSL Branch. Transport Problems, 12(4), pp. 27-36, https://doi.org/10.20858/tp.2017.12.4.3.

Weiland, D. (2018), Identifying the Impact of Information Logistics on Contemporary Conceptions of Logistics. Research Journal of University of Gdansk. Transport Economics and Logistics, 78, pp. 167-177, http://dx.doi.org/10.26881/etil.2018.78.14.

Wierzbowski, P. (2018), Application of Blockchain Technology in Information Management in Supply Chains. Research Journal of University of Gdańsk. Transport Economics and Logistics, 78, pp. 179-191, http://dx.doi.org/10.26881/etil.2018.78.15.

Zhan, F. (2019), Supplier Evaluation and Selection Method Based on Multi-Attribute Granulation. IOP Conference Series: Materials Science and Engineering, 490(4), pp. 1-6, https:// doi.org/10.1088/1757-899X/490/4/042029.

\section{Corresponding author}

Agnieszka Szmelter-Jarosz can be contacted at: a.szmelter@ug.edu.pl 